\title{
Analisis Pengaruh Kualitas Layanan terhadap Kepuasan dan Loyalitas Mahasiswa di Universitas AMIKOM Yogyakarta
}

\author{
Fatima Indah Hayati ${ }^{1}$, Zuprizal ${ }^{2}$, Singgih Hawibowo ${ }^{3}$, Yusuf Amri Amrullah ${ }^{4}$ \\ Universitas Gadjah Mada ${ }^{1,2,3}$, Universitas AMIKOM Yogyakarta ${ }^{4}$ \\ Fatimaindah15@gmail.com
}

\begin{abstract}
This research aims to know the influence of quality service toward the students' satisfaction and loyalty at AMIKOM Yogyakarta University. Research method is Quantitative Associative. The research participants of this research were 454 students who were chosen by purposive sampling technique. This research used a questionnaire that contained 41 questions. The result of this research was analyzed using Structural Equation Modeling (SEM) with the help of smartPLS v.3.2.8 program. The result of the analysis process showed: (1) Quality service had a significant and positive effect on the students' satisfaction with coefficient value of path analysis was 0.566. T statistic was 12.737 and the p-value was 0.000. Self Development Opportunity Dimension was the dimension which had the biggest influence toward the students' satisfaction, and internationalization dimension has the smallest influence toward the students' satisfaction, (2) Quality service had a significant and positive effect toward the students' loyalty with coefficient value of path analysis was 0.242, T statistic was 4.834 and the p-value was 0.000 . Self Development Opportunity Dimension was the dimension which had the biggest influence toward the students' satisfaction, and internationalization dimension has the smallest influence toward the students' satisfaction, (3) The students' satisfaction had significant and positive effect toward the students' loyalty with coefficient value of path analysis was 0.,516. T statistic was 10.919 and p-value was 0.000, (4) Students' satisfaction is partial mediation of the influence of quality service toward the students' loyalty with total effect value was 0,534.
\end{abstract}

Keywords: Service Quality; Students' Loyalty; Students' Satisfaction

\begin{abstract}
Abstrak : Penelitian ini bertujuan untuk mengetahui pengaruh kualitas pelayanan terhadap kepuasan dan loyalitas mahasiswa Universitas AMIKOM Yogyakarta. Metode penelitian yang digunakan adalah Quantitative Associative. Partisipan penelitian dalam penelitian ini adalah 454 siswa yang dipilih dengan teknik purposive sampling. Penelitian ini menggunakan kuesioner yang berisi 41 pertanyaan. Hasil penelitian ini dianalisis menggunakan Structural Equation Modeling (SEM) dengan bantuan program smartPLS v.3.2.8. Hasil proses analisis menunjukkan: (1) Kualitas pelayanan berpengaruh positif dan signifikan terhadap kepuasan siswa dengan nilai koefisien analisis jalur sebesar 0,566. T statistik adalah 12,737 dan p-value adalah 0,000. Dimensi Self Development Opportunity merupakan dimensi yang paling besar pengaruhnya terhadap kepuasan mahasiswa, dan dimensi internasionalisasi memiliki pengaruh paling kecil terhadap kepuasan mahasiswa, (2) Kualitas pelayanan berpengaruh signifikan dan positif terhadap loyalitas mahasiswa dengan nilai koefisien analisis jalur 0,242, T statistik 4,834 dan pvalue 0,000. Dimensi Self Development Opportunity merupakan dimensi yang paling besar pengaruhnya terhadap kepuasan siswa, dan dimensi internasionalisasi memiliki pengaruh paling kecil terhadap kepuasan siswa, (3) Kepuasan siswa berpengaruh signifikan dan positif
\end{abstract}

MANAZHIM : Jurnal Manajemen dan Ilmu Pendidikan

Volume 3, Nomor 2, Agustus 2021; 236-252

https://ejournal.stitpn.ac.id/index.php/manazhim 
terhadap loyalitas siswa dengan koefisien nilai analisis jalur adalah 0,516. T statistic sebesar 10,919 dan p-value sebesar 0,000, (4) Kepuasan mahasiswa merupakan mediasi parsial pengaruh kualitas pelayanan terhadap loyalitas mahasiswa dengan total effect value 0,534.

Kata Kunci: Kualitas Layanan; Loyalitas Siswa; Kepuasan Siswa

\section{PENDAHULUAN}

Era globalisasi menjadi era persaingan kualitas untuk segala bidang kehidupan. Produk yang berkualitas tentunya akan banyak diminati, begitu juga sebaliknya, produk yang tidak berkualitas maka akan ditinggalkan. Tidak terkecuali dalam bidang pendidikan, salah yang satunya adalah perguruan tinggi. Proses globalisasi memiliki berbagai macam bidang yaitu globalisasi ekonomi, globalisasi budaya, globalisasi komunikasi, dan globalisasi pendidikan ${ }^{1}$. Sejalan dengan hal tersebut maka diperlukan upaya untuk menghadapi persaingan dalam era globalisasi adalah dengan meningkatkan mutu institusi pendidikan baik dari segi kualitas pendidikan maupun kualitas pelayanan pendidikan yang diberikan kepada mahasiswanya.

Perguruan tinggi di Indonesia hingga tahun 2019 berjumlah 4.674 perguruan tinggi dengan rincian 68 Perguruan Tinggi Agama Negeri (PTAN), 285 Perguruan Tinggi Agama Swasta (PTAS), 66 Perguruan Tinggi Kementerian dan Litbang (PTKL), 91 Perguruan Tinggi Negeri (PTN), dan 1464 Perguruan Tinggi Swasta (PTS). Peningkatan jumlah perguruan tinggi tersebut mengakibatkan persaingan yang ketat dalam lingkungan pendidikan tinggi khususnya perguruan tinggi. Oleh karena itu, pengelola perguruan tinggi di Indonesia harus melakukan upaya-upaya untuk meningkatkan kinerjanya sehingga akan memberikan kepuasan kepada mahasiswa dengan melakukan pemenuhan keinginan dan kebutuhan mahasiswa. Kepuasan mahasiswa sebagai konsumen utama dalam sebuah institusi pendidikan merupakan hal yang penting yang harus diperhatikan, dan pengukuran tingkat kepuasan

${ }^{1}$ Bhagwati, Free Trade Today, (Princeton and Oxford: Princeton University Press, 2002), hlm. 96. 
mahasiswa berfungsi sebagai alat evaluasi dan pembelajaran bagi institusi pendidikan ${ }^{2}$.

Kepuasan mahasiswa diukur dari kesesuaian antara harapan dan kenyataan dari kualitas layanan yang mereka dapatkan. Ketika institusi pendidikan melakukan evaluasi terhadap kualitas yang diberikan, maka institusi pendidikan tersebut dapat melakukan perbaikan dan pengembangan yang bertujuan untuk meningkatkan kualitas layanannya. Kualitas layanan pendidikan yang baik dari sebuah institusi pendidikan akan memberikan dampak pada kepuasan mahasiswanya. Mahasiswa yang merasa puas terhadap layanan yang diterima, maka dapat menjadi seseorang yang loyal terhadap almamaternya. Mahasiswa yang loyal terhadap almamaternya maka akan menceritakan kepada orang lain tentang hal-hal positif terkait dengan alamamaternya.

Selain itu, mempertahankan mahasiswa merupakan hal yang sangat penting untuk diperhatikan oleh suatu perguruan tinggi seiring dengan meningkatnya persaingan antar perguruan tinggi di Indonesia. Keputusan mahasiswa atas pilihannya dalam menentukan perguruan tinggi sebagai tempat belajar harus diikuti juga dengan pemberian layanan yang berkualitas oleh perguruan tinggi yang dipilih oleh mahasiswa, dan juga mampu memberikan kepuasan kepada mahsiswa meskipun mahasiswa tersebut sudah menjadi alumni.

Perguruan tinggi harus bisa memahami apa yang mejadi kebutuhan mahasiswanya dan mampu memenuhi kebutuhan tersebut sehingga mahasiswa akan merasa puas dan loyal kepada perguruan tingginya. Perhatian terhadap loyalitas pelanggan khususnya loyalitas mahasiswa pada konteks lembaga pendidikan tinggi telah menjadi perhatian bagi kalangan akademisi pada sepuluh tahun terakhir ${ }^{3}$.

Perguruan tinggi sebagai lembaga pendidikan memiliki peran yang sangat penting dalam menghasilkan sumber daya manusia yang berkompeten. Perguruan Tinggi harus dikelola dengan berpedoman pada kepentingan sivitas akademika yang terdiri

${ }^{2}$ Ibrahim, M.Z., Rahman, M.N.A., dan Yasin, R.M, Assessing student perceptions of service quality in Technical Educational and Vocational Training (TEVT) Institution in Malaysia, dalam Jurnal Procedia-Social and Behavioral Science, (2012) hlm. 279.

${ }^{3}$ Suseno, Pengaruh Citra Program Studi, Citra Univesitas dan Kepuasan Mahasiswa terhadap Loyalitas Mahasiswa, (Yogyakarta: Universitas Gadjah Mada, 2012), hlm. 89. 
dari mahasiswa, tenaga pengajar, dan karyawan. Instansi yang menyelenggarakan pendidikan tinggi di Indonesia salah satunya adalah Universitas AMIKOM Yogyakarta. Universitas AMIKOM Yogyakarta yang sebelumnya bernama Sekolah Tinggi Manajemen Informatika dan Ilmu Komputer (STIMIK) AMIKOM Yogyakarta mengalami perubahan bentuk dari Sekolah Tinggi menjadi Universitas. Perubahan bentuk tersebut diputuskan melalui Izin Perubahan Bentuk dari Dirjen Pendidikan Tinggi (DIKTI) Kemenristekdikti dengan nomor surat 99/KPT/2017 pada tanggal 20 Januari 2017, dan hingga saat ini Universitas AMIKOM Yogyakarta memiliki 3 Fakultas dengan 16 program studi.

Pertumbuhan perguruan tinggi yang semakin meningkat, terutama perguruan tinggi swatsa, akan semakin memperketat persaingan antar perguruan tinggi yang ada di Indonesia. Oleh karena itu, tantangan tersebut, Unviersitas AMIKOM Yogyakarta sebagai salah satu perguruan tinggi swasta harus mampu bersaing dengan perguruan tinggi lainnya. Salah satunya dengan meningkatkan kualitas layanan yang diberikan kepada sivitas akademika terutama mahasiswa, sehingga akan menumbuhkan kepuasan dan loyalitas mahasiswa terhadap perguruan tingginya. Loyalitas mahasiswa merupakan salah satu faktor penting bagi keberlangsungan sebuah lembaga pendidikan tinggi dimana mahasiswa yang loyal terhadap perguruan tingginya akan memberikan dampak yang positif kepada perguruan tinggi itu sendiri ${ }^{4}$.

Dalam beberapa dekade terakhir, telah banyak dilakukan penelitian yang bertujuan untuk mengembangkan pemahaman hubungan konseptual antara kualitas layanan, kepuasan, dan loyalitas dengan tujuan untuk mengembangkan pemahaman yang jelas tentang tidak hanya kualitas dan kepuasan layanan tetapi juga tentang bagaimana kualitas layanan dan kepuasan tersebut saling berhubungan dan mampu memunculkan sikap loyal terhadap instansinya ${ }^{5}$.

Dalam kaitannya dengan studi tentang loyalitas mahasiswa, penelitian terhadap loyalitas mahasiswa dilatar belakangi oleh meningkatnya persaingan antar perguruan

\footnotetext{
${ }^{4}$ Ibid., hlm. 106.

${ }^{5}$ Cronin, J.J. Jr, Brady, M.K. dan Hult, G.T.M., Assessing the Effect of Quality, Value, and Consumer Satisfaction on Consumer Behavioral Intetntions in Service Environments, dalam Journal of Retailing, Vol. 76, No. 2, (2000), hlm. 202
} 
tinggi sebagai salah satu strategi orientasi pasar ${ }^{6}$. Kepuasan mahasiswa terhadap pengalaman dalam menempuh pembelajaran yang mereka terima di perguruan tinggi, dan persepsi positif terhadap perguruan tinggi akan berpengaruh positif terhadap loyalitas mahasiswa. Kepuasan mahasiswa merupakan kunci utama dari loyalitas mahasiswa, selain itu perguruan tinggi telah diakui sebagai industri jasa yang menekankan pentingnya memenuhi antara kebutuhan dan keinginan dari mahasiswanya. Upaya-upaya dalam memenuhi kebutuhan dan keinginan mahasiswa tersebut berarti perguruan tinggi juga berupaya untuk memberikan kepuasan kepada mahasiswanya ${ }^{7}$.

Saat ini, Universitas AMIKOM Yogyakarta merupakan salah satu perguruan tinggi yang berbentuk Universitas yang memiliki visi "Menjadi Perguruan Tinggi Unggulan Dunia Dalam Bidang Ekonomi Kreatif yang Berbasis Entrepreneurship”. Untuk dapat menjadi world class university perhatian dan atribut utama yang harus benar-benar diperhatikan adalah dalam hal kualitas ${ }^{8}$. Akan tetapi, dalam Renstra Universitas AMIKOM Yogyakarta tahun 2015-2020 disebutkan bahwa masih kurang berfungsinya secara efektif sistem manajemen penyelenggaraan akademik dan pelayanan kepada mahasiswa.

Berdasarkan beberapa hal di atas, maka penelitian ini befokus melakukan analisis pengaruh kualitas layanan terhadap kepuasan dan loyalitas mahasiswa di Universitas AMIKOM Yogyakarta. Universitas AMIKOM Yogyakarta belum pernah melakukan evaluasi secara menyeluruh terhadap pelayanan yang diberikan oleh institusinya kepada mahasiswa, sehingga informasi mengenai kualitas layanan terhadap kepuasan dan loyalitas mahasiswa masih belum terlalu banyak, dan hasil dari penelitian ini dapat digunakan sebagai salah satu strategi yang digunakan untuk arah pengembangan Universitas AMIKOM Yogyakarta.

${ }^{6}$ Helgesen, O. dan Nesset, E., Image, Satisfaction, and Antecedents: Driver of Student Loyalty? A Case Study of a Norwegian University College, dalam Corporate Reputation Review, Vol. 10, No. 1, (2007), hlm. 42.

7 Thomas, S., What Drives Student Loyalty in Universities: An Empirical Model From India dalam International Business ResearchVol. 4, No. 2, (2011), hlm. 186.

${ }^{8}$ Jusoh, A. dkk, Service Quality in Higher Education: Management Student's Perspective, (University of Ted 40 ology Malaysia: Research Management Centre., 2004), hlm. 2 
Dalam penelitian ini, layanan perguruan tinggi diukur dengan menggunakan adopsi tiga instrumen pengukuran kualitas layanan perguruan tinggi bernama HEdPERF oleh Abdullah pada tahun 2005 yang melakukan penelitian dengan instrumen tersebut di perguruan tinggi di Malaysia, HEdQual oleh Icli dan Anil pada tahun 2014 yang melakukan penelitian dengan instrumen tersebut di perguruan tinggi di Turki, dan HiEDQUal oleh Annamdevulla dan Bellamkonda pada tahun 2016 yang melakukan penelitian dengan instrumen tersebut di perguruan tinggi di India. Dari 3 instrumen penelitian tentang kualitas layanan di perguruan tinggi tersebut, kemudian dalam penelitian ini dimensi kualitas layanan disesuaikan dengan keadaan dan kebutuhan dari Universitas AMIKOM Yogyakarta dimana penyesuaian tersebut didasarkan pada Renstra Universitas AMIKOM Yogyakarta tahun 2015-2020, wawancara dengan dosen Universitas AMIKOM Yogyakarta, dan data observasi pendahuluan terhadap mahasiswa Universitas AMIKOM Yogyakarta, sehingga didapatkan bahwa kualitas layanan dalam penelitian ini terdiri dari tujuh dimensi layanan, yaitu dimensi akademik, fasilitas akademik, perpustakaan, administrasi, infrastruktur kampus, peluang pengembangan diri, dan internasionalisasi.

Selanjutnya, kepuasan mahasiswa diukur dengan mengadopsi kuesioner tentang kepuasan dari Anderson dan Srinivasan pada tahun 2003 yang terdiri dari empat item pertanyaan tentang kepuasan yang disesuaikan dalam konteks kepuasan mahasiswa Universitas AMIKOM Yogyakarta'. Kemudian yang terakhir adalah loyalitas, ditunjukkan dengan adanya positive word of mouth, retensi mahasiswa, dan kecenderungan mahasiswa untuk merekomendasikan Universitas AMIKOM Yogyakarta kepada orang lain sebagai tempat untuk melanjutkan studi. Kuesioner loyalitas tersebut diadopsi dari teori-teori tentang loyalitas dan kuesioner penelitian dari Chaudhurri dan Holbrook pada tahun 2001 dengan dilakukan modifikasi oleh penulis dan disesuaikan dengan konteks loyalitas mahasiswa di Universitas AMIKOM Yogyakarta yang terdiri dari tiga item pertanyaan.

Berdasarkan latar belakang dan teori yang sudah dipaparkan, maka kerangka dari penelitian ini adalah sebagai berikut:

9 Anderson, R.E. dan Srinivasan, S.S., E-Satisfaction and E-Loyalty: A Contingency Framework, dalam Psychology \& Marketing, Vol. 20, No. 2, (2003), hlm. 134-135. 


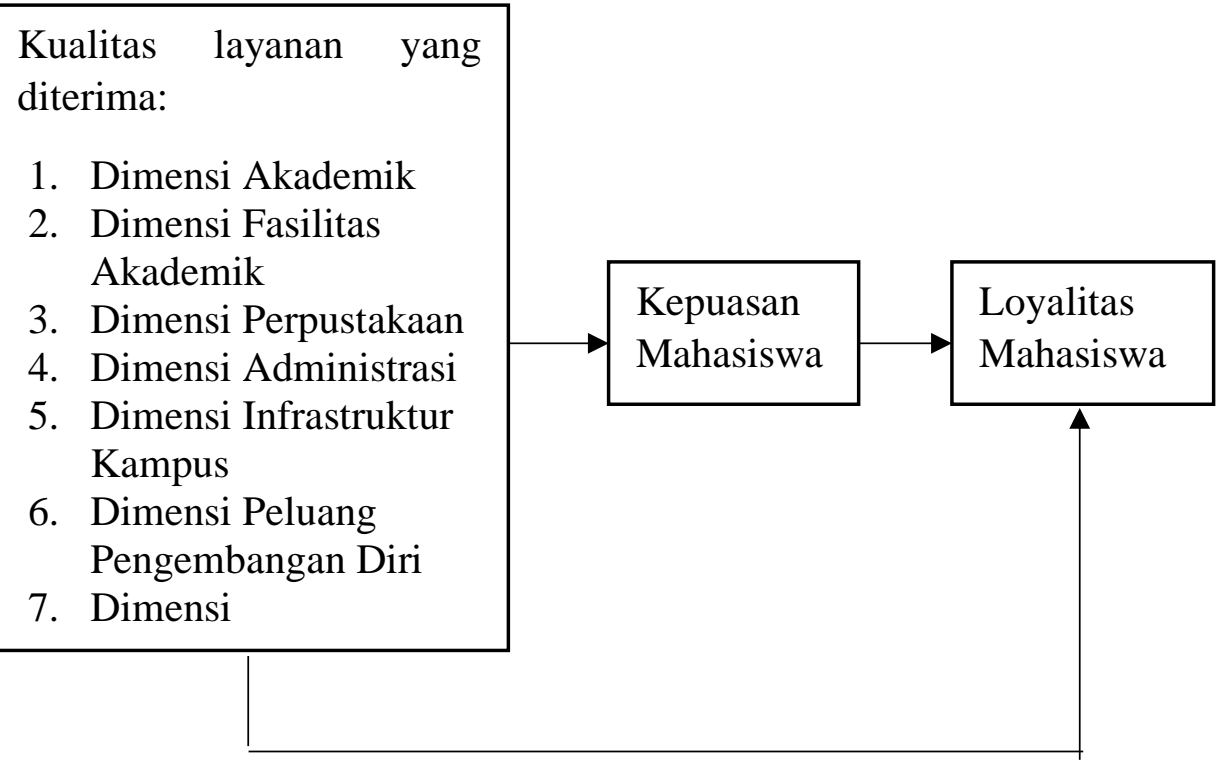

Gambar 1. Kerangka Konsep Penelitian

Kemudian dari gambar di atas maka dapat dijelaskan hipotesis penelitian adalah sebagai berikut:

$\mathrm{H}_{1}$ : Kualitas layanan berpengaruh terhadap kepuasan mahasiswa Universitas AMIKOM Yogyakarta

$\mathrm{H}_{2}$ : Kualitas layanan berpengaruh terhadap loyalitas mahasiswa Universitas AMIKOM Yogyakarta

$\mathrm{H}_{3}$ : Kepuasan mahasiswa berpengaruh terhadap loyalitas mahasiswa di Universitas AMIKOM Yogyakarta.

$\mathrm{H}_{4}$ : Kepuasan mahasiswa sebagai mediator pengaruh kualitas layanan terhadap loyalitas mahasiswa di Universitas AMIKOM Yogyakarta.

\section{METODE}

Metode yang digunakan dalam penelitian ini adalah kuantitatif asosiatif. Penelitian kuantitatif merupakan pendekatan untuk menguji teori subjektif dengan melakukan uji hubungan antar variabel dimana variabel tersebut dapat diukur dengan menggunakan instrumen sehingga jumlah data dapat dianalisis dengan menggunakan 
prosedur statistik ${ }^{10}$. Penelitian asosiatif adalah penelitian yang tujuannya untuk mengetahui pengaruh atau hubungan antara dua variabel atau lebih ${ }^{11}$. Desain korelasional digunakan dalam penelitian ini, dimana peneliti menggunakan statistik korelasional untuk menggambarkan dan mengukur asosiasi atau hubungan antara dua variabel atau lebih dalam suatu penelitian.

Pengambilan sampel dilakukan menggunakan non probability sampling dengan metode purposive sampling. Purposive sampling merupakan teknik dalam menentukan sampel dengan pertimbangan atau kriteria tertentu ${ }^{12}$. Kriteria sampel dari penelitian ini adalah mahasiswa aktif Universitas AMIKOM yang terdiri dari 3 kelompok sampel dan terbagi dalam 15 program studi. Kelompok sampel tersebut yaitu mahasiswa jenjang D3 (angkatan 2017), S1 (angkatan 2016 untuk program studi lama dan angkatan 2017 untuk program studi baru) karena mahasiswa angkatan tersebut setidaknya sudah menempuh tahun kedua untuk mahasiswa D3 dan tahun ke tiga dan ke dua untuk mahasiswa S1 sehingga dianggap cukup mampu untuk memberikan penilaian terhadap kualitas layanan yang diberikan Universitas AMIKOM Yogyakarta serta dapat memberikan informasi yang dibutuhkan dalam penelitian ini.

Kuesioner penelitian yang terdiri dari 41 pernyataan disebarkan melalui link google form dan lembar kuesioner. Untuk mengetahui tingkat persepsi responden, digunakan skala Likert dengan pilihan jawaban $1=$ sangat tidak setuju sampai dengan $5=$ sangat setuju. Analisis data yang digunakan dalam penelitian ini adalah Structural Equation Modelling (SEM). Pengolahan data dilakukan dengan bantuan program SmartPLS v.3.2.8. Dalam SEM, metode analisis data dilakukan dengan dua tahap yaitu (1) evaluasi model pengukuran atau outer model yang dilakukan untuk menilai validitas dan reliabilitas variabel penelitian, (2) evaluasi model struktural atau inner model yang dilakukan untuk melakukan fit model dan uji hopotesis.

10 Creswell, J. W., Research Design: Pendekatan Metode Kualitatif, Kuantitatif dan Campuran, (Yogyakarta: Pustaka Pelajar, 2016), hlm. 26.

11 Sugiyono, Statistika untuk Penelitian, (Bandung: Alfabeta, 2015), hlm. 56

12 Ibid., hlm. 125 


\section{HASIL DAN PEMBAHASAN}

Pada penelitian ini, demografi responden dilihat berdasarkan 4 kategori yaitu jenjang pendidikan, jenis kelamin, umur, dan aasal daerah yang dijabarkan pada tabel di bawah ini.

Tabel 1. Kategorisasi Responden Penelitian

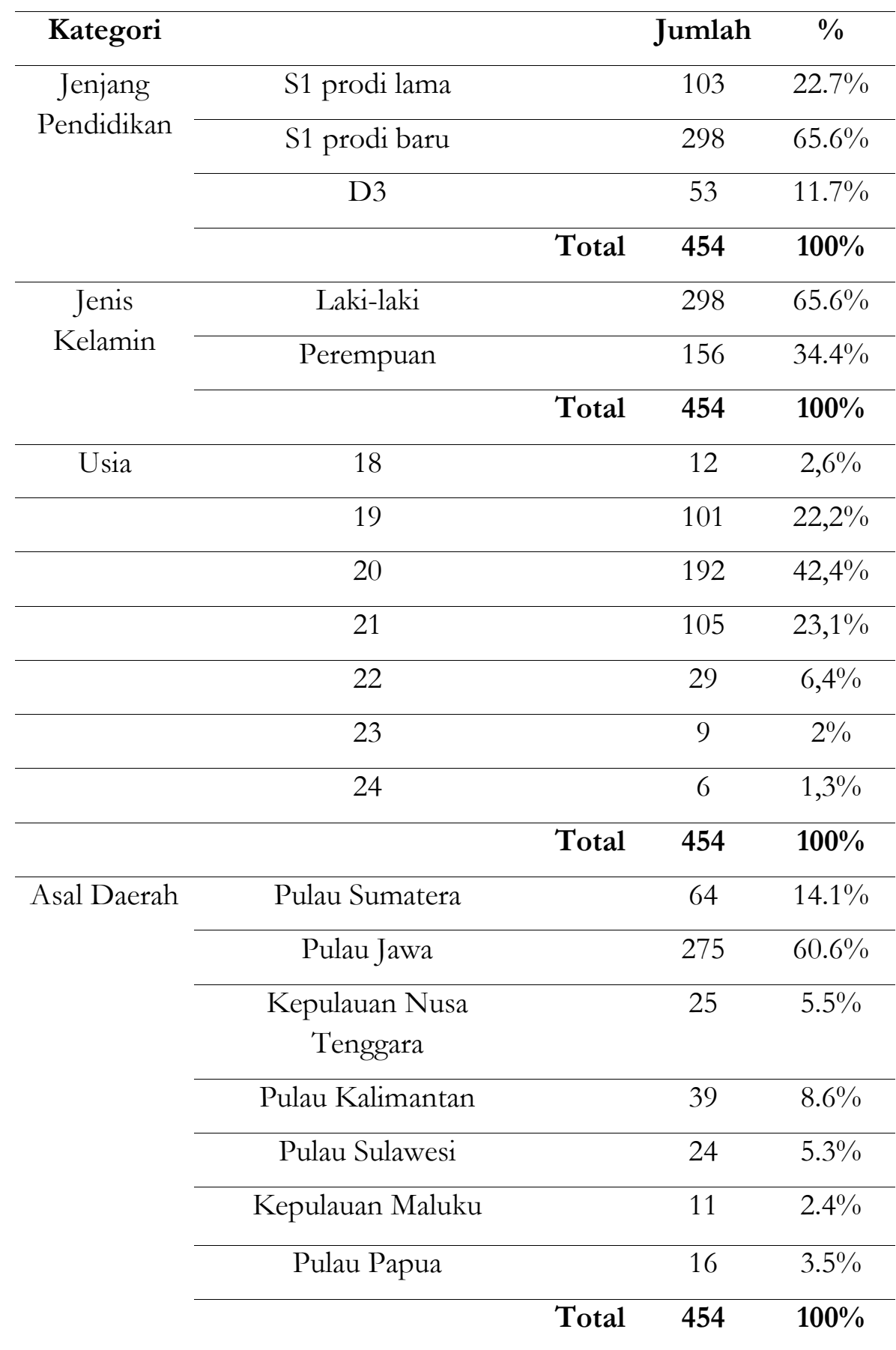

Sumber: Data primer diolah, 2019 


\section{Diagram Jalur Penelitian}

Langkah pertama yang harus dilakukan sebelum menilai outer model dan inner model yaitu menyiapkan sebuah diagram yang mengilustrasikan hipotesis dan menggambarkan hubungan antara variabel yang akan diuji.

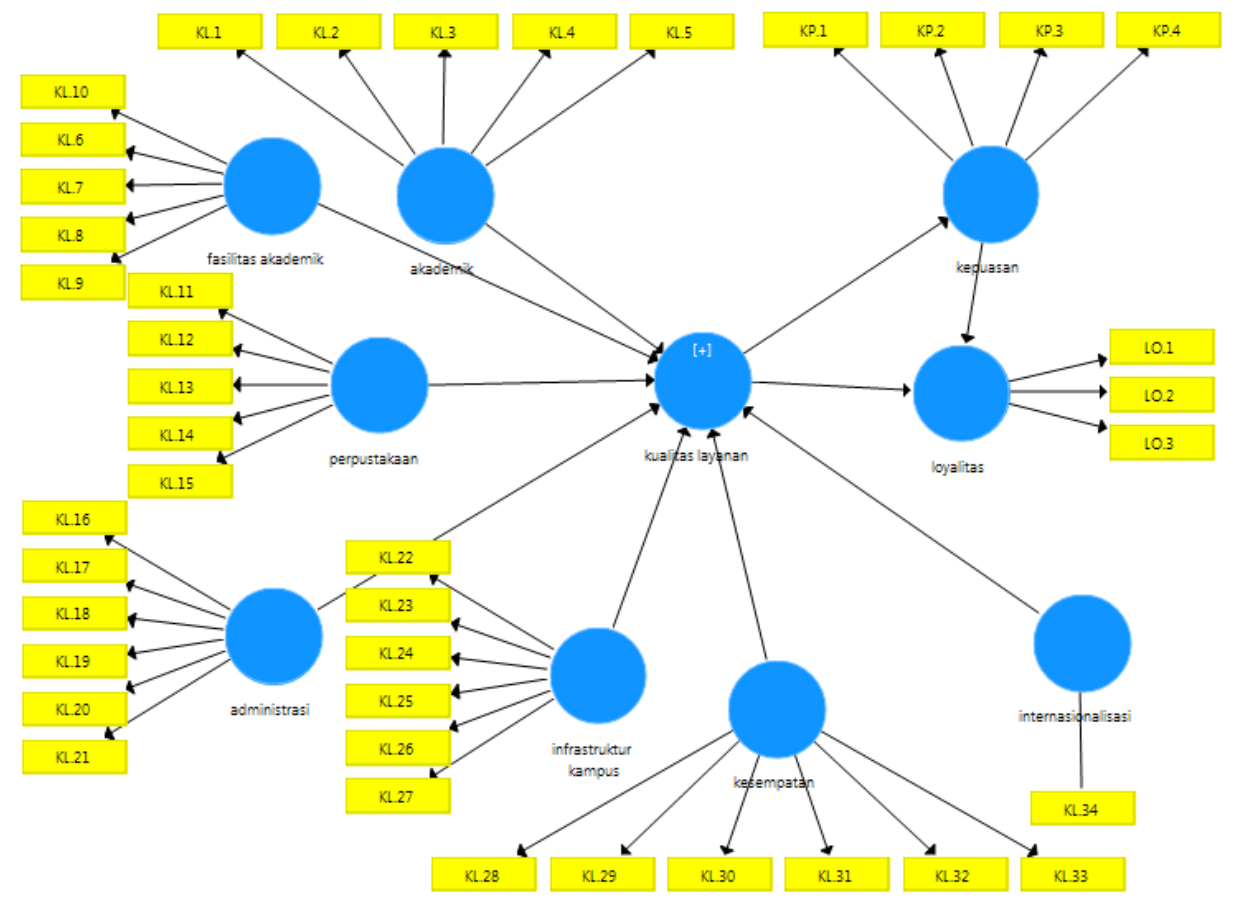

Gambar 2. Diagram Jalur Penelitian

Sumber: Output SmartPLS v.3.2.8, 2019

\section{Uji Validitas dan Reliabilitas}

Evaluasi model pengukuran untuk mengukur validitas dan reliabilitas dilakukan dengan memeriksa 1) validitas konvergen dengan keseluruhan nilai AVE pada setiap variabel dan dimensi adalah lebih dari 0,$5 ; 2$ ) validitas diskriminan dengan melihat nilai HTMT yang harus kurang dari 0,9 , nilai cross loading setiap indikator harus lebih dari indikator yang lainnya, nilai Fornell-Larcker Criterion setiap variabel harus lebih besar dari variabel lainnya; 3) reliabilitas indikator dilihat dari nilai outer loading yang harus lebih dari 0,7, dan; 4) reliabilitas konsistensi internal dengan meliahar nilai reliabilitas komposit dan cronbach's alpha yang harus lebih dari 0,7. 


\section{Analisis Hasil Pengujian Hipotesis}

Berdasarkan hasil pengujian hipotesis, maka diketahui bahwa dari empat hipotesis yang diajukan, semuanya diterima.

Tabel 2. Rekapitulasi Hipotesis

\begin{tabular}{|c|c|}
\hline Hipotesis & Status \\
\hline $\begin{array}{l}\mathrm{H}_{1} \quad \text { Kualitas layanan berpengaruh terhadap kepuasan mahasiswa } \\
\text { Universitas AMIKOM Yogyakarta }\end{array}$ & Diterima \\
\hline $\begin{array}{ll}\mathrm{H}_{2} & \text { Kualitas layanan berpengaruh terhadap loyalitas mahasiswa } \\
& \text { Universitas AMIKOM Yogyakarta }\end{array}$ & Diterima \\
\hline $\begin{array}{l}\mathrm{H}_{3} \text { Kepuasan mahasiswa berpengaruh terhadap loyalitas mahasiswa } \\
\text { di Universitas AMIKOM Yogyakarta. }\end{array}$ & Diterima \\
\hline $\begin{array}{l}\mathrm{H}_{4} \text { Kepuasan mahasiswa memediasi pengaruh kualitas layanan } \\
\text { terhadap loyalitas mahasiswa di Universitas AMIKOM } \\
\text { Yogyakarta }\end{array}$ & Diterima \\
\hline
\end{tabular}

Sumber: Data primer diolah, 2019

\section{Pengaruh Kualitas Layanan terhadap Kepuasan Mahasiswa}

Evaluasi kepuasan mahasiswa terhadap kualitas layanan merupakan faktor kunci dalam upaya untuk meningkatkan kualitas layanan suatu perguruan tinggi. Dari hasil pengujian hipotesis, kualitas layanan menunjukkan pengaruh positif dan signifikan pada kepuasan mahasiswa dengan nilai p sebesar 0,000 $(<0,05)$, nilai t statistik sebesar 12,737 (> 1,96) dan nilai koefisien jalur sebesar 0,566 yang berarti bernilai positif. Hal tersebut membuktikan bahwa kualitas layanan secara positif memberikan pengaruh terhadap kepuasan mahasiswa. Semakin tinggi dan baik kualitas layanan yang diberikan oleh Universitas AMIKOM Yogyakarta maka semakin tinggi juga tingkat kepuasan mahasiswanya.

Selanjutnya, nilai R square variabel kualitas layanan terhadap kepuasan mahasiswa adalah 0,320 atau 32\% yang artinya kepuasan mahasiswa sebesar 32\% dijelaskan oleh kualitas layanan, dan 68\% sisanya dijelaskan oleh variabel lain di luar penelitian ini. 
Hasil dari penelitian ini juga menunjukkan bahwa kualitas layanan yang sesuai dengan harapan, maka akan membuat mahasiswa merasa puas. Kualitas layanan tersebut terdiri dari tujuh dimensi kualitas layanan perguruan tinggi yaitu dimensi akademik, fasilitas akademik, perpustakaan, administrasi, infrastruktur kampus, peluang pengembangan diri, dan internasionalisasi, dimana tujuh dimensi tersebut secara keseluruhan memberikan pengaruh yang positif dan signifikan terhadap kepuasan mahasiswa di Universitas AMIKOM Yogyakarta. Dari tujuh dimensi kualitas layanan di atas, dimensi yang paling berpengaruh terhadap kepuasan mahasiswa adalah dimensi peluang pengembangan diri dilihat dari nilai koefisien jalur sebesar 0,155. Dimensi peluang pengembangan diri yang terdiri dari indikator variasi minat studi, wadah pengembangan minat bakat mahasiswa, dan peluang karir mahasiswa perlu untuk dipertahankan.

Dengan adanya layanan peluang pengembangan diri, mahasiswa dapat menyalurkan minat dan bakat atau potensi diri mereka secara optimal, sehingga mereka dapat menjadi pribadi yang profesional dibidang keahlian masing-masing. Selain itu, ketersediaan pusat karir yang diberikan oleh suatu perguruan tinggi untuk mahasiswa merupakan indikator dan bukti bahwa output dari Universitas AMIKOM Yogyakarta dapat dipertanggungjawabkan dan diperlukan oleh para penyedia lapangan pekerjaan. Hal tersebut sejalan dengan penelitian oleh Pramana (2002) yang menyebutkan bahwa kondisi lokasi belajar, fasilitas pengajaran, isu program dan informasi karir atau pekerjaan merupakan aspek yang dianggap paling penting oleh mahasiswa yang harus diperhatikan kualitas kayanannya dalam perguruan tinggi ${ }^{13}$.

\section{Pengaruh Kualita Layanan Terhadap Loyalitas Mahasiswa}

Kualitas layanan berpengaruh positif dan signifikan pada loyalitas mahasiswa dengan nilai p sebesar $0,000(<0,05)$, nilai t statistik sebesar 4,834 $(>1,96)$ dan nilai koefisien jalur sebesar 0,242 yang berarti bernilai positif. Hal tersebut membuktikan bahwa kualitas layanan memberikan pengaruh terhadap loyalitas mahasiswa, serta

13 Pramana, C. Persepsi Mahasiswa terhadap Kualitas Pelayanan Perguruan Tinggi dengan Menggunakan Analisis Importance-Performance Sebagai Alat Stratejik, (Yogyakarta: Universitas Gadjah Mada, 2002), hlm. 154. 
semakin baik kualitas layanan yang diberikan oleh Universitas AMIKOM Yogyakarta maka semakin tinggi juga tingkat loyalitas mahasiswa.

Selanjutnya, nilai $\mathrm{R}$ square variabel kualitas layanan terhadap loyalitas mahasiswa adalah 0,466 atau 46,6\% yang artinya loyalitas mahasiswa sebesar 46,6\% dijelaskan oleh kualitas layanan, dan 53,4\% sisanya dijelaskan oleh variabel lain di luar penelitian ini. Kualitas layanan Universitas AMIKOM Yogyakarta terdiri dari tujuh dimensi yaitu dimensi kualitas layanan akademik, fasilitas akademik, perpustakaan, administrasi, infrastruktur kampus, peluang pengembangan diri, dan internasionalisasi, dimana tujuh dimensi tersebut semuanya memberikan pengaruh yang positif dan signifikan terhadap loyalitas mahasiswa di Universitas AMIKOM Yogyakarta.

Semakin banyak mahasiswa yang memiliki rasa loyal terhadap Universitas AMIKOM Yogyakarta akan sangat menguntungkan dikarenakan Universitas AMIKOM Yogyakarta saat ini sedang berfokus dalam melakukan pengembangan institusi dan juga Universitas AMIKOM Yogyakarta baru saja mengalami perubahan bentuk dari Sekolah Tinggi menjadi Universitas pada tahun 2017. Oleh karena itu, tentunya banyak tantangan yang harus dihadapi dan kegiatan pengembangan yang harus dilakukan. Salah satunya dengan selalu meningkatkan kualitas layanan yang diberikan sehingga akan semakin banyak masyarakat yang mempercayakan pendidikan tingginya di Universitas AMIKOM Yogyakarta.

Selain itu, dengan memberikan pelayanan yang baik kepada mahasiswanya, maka akan membetuk sikap loyal mahasiswa terhadap Universitas AMIKOM Yogyakarta yang tercermin dalam beberapa sikap mahasiswa terhadap Universitas AMIKOM Yogyakarta yaitu mahasiswa akan memberikan informasi positif kepada orang lain mengenai Universitas AMIKOM Yogyakarta, mahasiswa tidak tertarik untuk berpindah ke perguruan tinggi lain, dan akan merekomendasikan Universitas AMIKOM Yogyakarta kepada orang lain (saudara, tetangga, dan lain sebagainya) sebagai tempat untuk melanjutkan studi pada jenjang pendidikan tinggi.

Dari tujuh dimensi kualitas layanan yang telah disebutkan di atas, dimensi yang paling berpengaruh terhadap loyalitas mahasiswa adalah dimensi peluang pengembangan diri dilihat dari nilai koefisien jalur sebesar 0,146. Dimensi peluang 
pengembangan diri yang terdiri dari indikator variasi minat studi, wadah pengembangan minat bakat mahasiswa, dan peluang karir mahasiswa perlu untuk dipertahankan. Ketersediaan pusat karir yang diberikan oleh suatu perguruan tinggi untuk mahasiswa merupakan indikator dan bukti bahwa output dari Universitas AMIKOM Yogyakarta dapat dipertanggungjawabkan dan diperlukan oleh para penyedia lapangan pekerjaan.

\section{Pengaruh Kepuasan Mahasiswa terhadap Loyalitas Mahasiswa}

Kepuasan mahasiswa menunjukkan pengaruh positif dan signifikan pada loyalitas mahasiswa dengan nilai p sebesar 0,000 (<0,05), nilai t statistik sebesar 10,919 (> 1,96) dan nilai koefisien jalur sebesar 0,516 yang berarti bernilai positif. Hal tersebut membuktikan bahwa kepuasan mahasiswa memberikan pengaruh terhadap loyalitas mahasiswa, serta semakin tinggi kepuasan mahasiswa maka semakin tinggi juga tingkat loyalitas mahasiswa. Loyalitas mahasiswa dicerminkan dalam beberapa sikap yaitu mahasiswa akan memberikan informasi positif kepada orang lain mengenai Universitas AMIKOM Yogyakarta, mahasiswa tidak tertarik untuk berpindah ke perguruan tinggi lain, dan akan merekomendasikan Universitas AMIKOM Yogyakarta kepada orang lain (saudara, tetangga, dan lain sebagainya) sebagai tempat untuk melanjutkan studi pada jenjang pendidikan tinggi.

\section{Kepuasan Mahasiswa sebagai Mediasi Pengaruh Kualitas Layanan terhadap}

\section{Loyalitas Mahasiswa}

Kepuasan mahasiswa terbukti memediasi variabel kualitas layanan terhadap loyalitas mahasiswa yang dilihat dari pengaruh langsung dan tidak langsung kualitas layanan terhadap loyalitas mahasiswa sebagai berikut:

1. Pengaruh kualitas layanan terhadap kepuasan mahasiswa adalah signifikan dengan koefisien jalur sebesar 0,566, nilai p sebesar 0,000 $(<0,05)$ dan t statistik sebesar $12,737(>1,96)$. 
2. Pengaruh langsung kualitas layanan terhadap loyalitas juga signifikan dengan koefisien jalur sebesar 0,242, nilai p sebesar $0,000(<0,05)$, dan t statistik sebesar 4,834 (>1,96).

3. Pengaruh kepuasan mahasiswa terhadap loyalitas mahasiswa juga signifikan dengan nilai koefisien jalur sebesar 0,516, nilai p sebesar 0,000 $(<0,05)$, dan $\mathrm{t}$ statistik sebesar 10,919 ( > 1,96).

4. Pengaruh tidak langsung kualitas layanan terhadap loyalitas mahasiswa (melalui kepuasan mahasiswa) memiliki nilai koefisien jalur sebesar 0,292, nilai p 0,000 (< 0,05), dan dengan nilai t statistik 8,127 ( > 1,96).

Tabel 3. Efek Langsung, Efek Tidak Langsung, dan Efek Total

\begin{tabular}{lccc}
\hline \multicolumn{1}{c}{ Variabel } & $\begin{array}{c}\text { Efek } \\
\text { Langsung }\end{array}$ & $\begin{array}{c}\text { Efek Tidak } \\
\text { Langsung }\end{array}$ & $\begin{array}{c}\text { Efek } \\
\text { Total }\end{array}$ \\
\hline $\begin{array}{l}\text { Kualitas Layanan } \rightarrow \text { Kepuasan } \\
\text { Mahasiswa }\end{array}$ & 0,566 & 0,000 & 0,566 \\
\hline $\begin{array}{l}\text { Kepuasan Mahasiswa } \rightarrow \text { Loyalitas } \\
\text { Mahasiswa }\end{array}$ & 0,516 & 0,000 & 0,516 \\
\hline $\begin{array}{l}\text { Kualitas Layanan } \rightarrow \text { Loyalitas } \\
\text { Mahasiswa }\end{array}$ & 0,242 & 0,292 & 0,534 \\
\hline
\end{tabular}

Sumber: Output SmartPLS v.3.2.8, 2019

Hal tersebut menunjukkan bahwa kepuasan mahasiswa memediasi pengaruh kualitas layanan terhadap loyalitas dimana kepuasan mahasiswa perpengaruh sebagian atau parsial dari pengaruh kualitas layanan terhadap loyalitas mahasiswa. Loyalitas mahasiswa terbentuk sebagai akibat dari kualitas layanan dan kepuasan mahasiswa Universitas AMIKOM Yogyakarta. Mahasiswa yang merasa puas dengan pelayanan yang diberikan oleh Universitas AMIKOM Yogyakarta akan membetuk sikap loyal mahasiswa terhadap Universitas AMIKOM Yogyakarta. Hal tersebut memperlihatkan bahwa kepuasan yang tinggi pada kualitas layanan yang diberikan oleh suatu perguruan tinggi dapat mendorong tingginya loyalitas mahasiswa. 
Perguruan tinggi yang memiliki persepsi kepuasan yang baik dan mampu mempertahankan dan bahkan meningkatkan kualitas layanannya maka akan membuka peluang bagi mahasiswa untuk memberikan rekomendasi kepada orang lain untuk melanjutkan studi pada jenjang pendidikan tinggi di tempat mereka belajar saat ini. Loyalitas mahasiswa di sini merupakan salah satu dampak dari kepuasan yang dirasakan oleh mahasiswa atas pelayanan yang diberikan oleh Universitas AMIKOM Yogyakarta.

\section{KESIMPULAN}

Kualitas layanan pada dimensi akademik, fasilitas akademik, perpustakaan, administrasi, infrastruktur kampus, peluang pengembangan diri, dan internasionalisasi berpengaruh positif dan signifikan terhadap kepuasan dan loyalitas mahasiswa. Dimensi yang paling berpengaruh adalah dimensi peluang pengembangan diri dengan indikator variasi minat studi, wadah pengembangan minat bakat mahasiswa, dan peluang karir mahasiswa. Dimensi yang memiliki pengaruh terkecil adalah dimensi internasionalisasi dengan indikator kerjasama internasional.

Kepuasan mahasiswa berpengaruh terhadap loyalitas mahasiswa. Kepuasan mahasiswa juga berperan sebagai variabel mediasi parsial. Dengan demikian berarti kualitas layanan berpengaruh terhadap loyalitas mahasiswa baik secara langsung maupun melalui mediasi kepuasan mahasiswa.

Meskipun mahasiswa menganggap kualitas layanan dalam kategori penilaian sedang, namun hasil penelitian menunjukkan tingginya kepuasan mahasiswa dan loyalitas mahasiswa terhadap terhadap Universitas AMIKOM Yogyakarta. Dengan demikian dapat disimpulkan bawha ada variabel lain di luar model penelitian ini yang juga mempengaruhi kepuasan dan loyalitas mahasiswa. 


\section{DAFTAR PUSTAKA}

Abdullah, F. (2005). The Development of HEdPERF: A New Measuring Instrument of Service Quality for The Higher Education Sector. International Journal of Consumer Studies, 30(6): 569-581.

Anderson, R.E. dan Srinivasan, S.S. (2003). E-Satisfaction and E-Loyalty: A Contingency Framework. Psychology \& Marketing, 20(2): 123-137.

Annamdevula, S. dan Bellamkonda, R.S. (2016). The Effects of Service Quality on Student Loyalty: The Mediating Role of Student Satisfaction. Journal of Modelling in Management, 11(2): 446-462.

Bhagwati, J. (2002). Free Trade Today. Princeton and Oxford: Princeton University Press.

Creswell, J. W. (2016). Research Design: Pendekatan Metode Kualitatif, Kuantitatif dan Campuran. Yogyakarta: Pustaka Pelajar.

Cronin, J.J. Jr, Brady, M.K. dan Hult, G.T.M. (2000). Assessing the Effect of Quality, Value, and Consumer Satisfaction on Consumer Behavioral Intetntions in Service Environments. Journal of Retailing, 76(2): 193-218.

Helgesen, O. dan Nesset, E. (2007). Image, Satisfaction, and Antecedents: Driver of Student Loyalty? A Case Study of a Norwegian University College. Corporate Reputation Review, 10(1): 38-59.

Ibrahim, M.Z., Rahman, M.N.A., dan Yasin, R.M. (2012). Assessing student perceptions of service quality in Technical Educational and Vocational Training (TEVT) Institution in Malaysia. Procedia-Social and Behavioral Sciences, 56: $272-283$.

Icli, G.E. dan Anil, N.K. (2014). The HEDQUAL scale: A new measurement scale of service quality for MBA programs in higher education. A.Afr.J.Bus.Manage, 45(3): 31-43.

Jusoh, A., Omain, S.Z., Majid, N.A., Som, H.M.D., dan Shamsuddin, A.S. (2004). Service Quality in Higher Education: Management Student's Perspective. University of Technology Malaysia: Research Management Centre.

Pramana, C. (2002). Persepsi Mahasiswa terhadap Kualitas Pelayanan Perguruan Tinggi dengan Menggunakan Analisis Importance-Performance Sebagai Alat Stratejik. Tesis. Yogyakarta: Universitas Gadjah Mada.

Sugiyono. (2015). Statistika untuk Penelitian. Bandung: Alfabeta.

Suseno, A.E. (2012). Pengaruh Citra Program Studi, Citra Univesitas dan Kepuasan Mahasiswa terhadap Loyalitas Mahasiswa. Tesis. Yogyakarta: Universitas Gadjah Mada.

Thomas, S. (2011). What Drives Student Loyalty in Universities: An Empirical Model From India. International Business Research, 4(2): 183-192. 